\title{
Pengaruh Komunikasi Orangtua terhadap Perilaku Agresif verbal Anak Usia 5-6 Tahun
}

\author{
Yusri E. Siahaan ${ }^{1 凶}$, Panggung Sutapa ${ }^{2}$, Anita Yus ${ }^{3}$ \\ Pendidikan Anak Usia Dini, Universitas Negeri Yogyakarta(1,2) \\ Pendidikan Anak Usia Dini, Universitas Negeri Medan(3) \\ DOI: $10.31004 /$ obsesi.v5i2.890
}

\begin{abstract}
Abstrak
Penelitian ini bertujuan untuk mengetahui, bentuk agresif verbal anak usia 5-6 tahun, bentuk komunikasi orang tua anak yang cenderung berperilaku agresif verbal, dan perbedaan perilaku agresif verbal anak dilihat berdasarkan komunikasi orang tua pada anak usia 5-6 Tahun. Penelitian ini merupakan penelitian deskriptif kuantitatif dengan metode komparatif dengan sampel sebanyak 40 anak. Variabel yang digunakan dalam penelitian ini adalah komunikasi orang tua $(X)$, dan perilaku agresif verbal anak $(Y)$. Data dikumpulkan menggunakan observasi dan angket. Observasi dilakukan untuk melihat perilaku agresif verbal anak, dan angket untuk melihat jenis komunikasi orang tua. Hasil penelitian ini menunjukkan bahwa; bentuk agresif verbal anak usia 5-6 tahun adalah respon anak dalam bentuk kata-kata kasar, bentuk komunikasi anak yang cenderung berperilaku agresif verbal adalah komunikasi tidak terbuka, komunikasi mengabaikan, komunikasi otoriter, komunikasi satu arah dan tanpa ada komunikasi, dan jenis komunikasi satu arah memiliki tingkat agresif verbal anak yang lebih tinggi dari jenis komunikasi lainnya.
\end{abstract}

Kata Kunci: komunikasi orang tua; perilaku agresif verbal; anak usia dini

\begin{abstract}
This study aims to find out, the verbal aggressive form of children aged 5-6 years, the form of communication of parents of children who tend to behave verbally aggressively, difference in verbal aggressive behavior of children seen based on parental communication in children aged 5-6 Years. This research is a quantitative descriptive research with comparative methods with a sample of 40 children. The variables used in this study were parental communication (X), and the child's verbal aggressive behavior ( $\mathrm{Y}$ ). Data is collected using observations and questionnaires. Observations were made to look at the child's verbal aggressive behavior, and a questionnaire was conducted to see the type of parental communication. The results of this study showed that; verbal aggressive form of children aged 5-6 years is the response of the child in the form of harsh words, the forms of communication of the child who tend to behave aggressively verbally is non-open communication, neglect communication, authoritarian communication, one-way communication and without any, and this type of one-way communication has a an aggressive level of verbality of the child that is better than other types of communication.
\end{abstract}

Keywords: parental communication; verbal aggressive behavior; early childhood.

Copyright (c) 2020 Yusri E. Siahaan, Panggung Sutapa, Anita Yus

$\triangle$ Corresponding author :

Email Address : yusrie.2019@student.uny.ac.id (Yogyakarta, Indonesia)

Received 9 November 2020, Accepted 26 November 2020, Published 29 November 2020 


\section{PENDAHULUAN}

Anak usia dini membutuhkan rangsangan pembelajaran untuk tumbuh dan berkembang. Anak-anak dalam setiap proses pertumbuhan dan perkembangan, akan membutuhkan lingkungan yang dapat memberi mereka pengalaman hidup (Trivette et al., 2010). Lingkungan yang paling dekat dengan anak adalah lingkungan keluarga dan lingkungan sekolah. Dalam lingkungan keluarga, anak akan tumbuh dan berkembang melalui orang tua (Irma et al., 2019). Menurut hasil penelitian yang dilakukan di TK Kenanga Kabupaten Bandung barat, menemukan bahwa keterlibatan orang tua akan sangat berpengaruh terhadap perilaku anak usia dini (Robbiyah et al., 2018). Selain itu, menurut Turney and Kao, keluarga memiliki peran yang sangat penting bagi perkembangan anak, karena keluarga merupakan tempat pertama pembentuk pengalaman anak dan yang akan membantu perkembangan anak hingga ke masa depan nanti (Albaiz \& Ernest, 2020). Satusatunya konteks yang paling kuat untuk pembentukan perilaku dan sikap anak terjadi di dalam rumah, karena dari sanalah anak mulai belajar (Britto et al., 2017).

Anak akan tumbuh dan berkembang dengan lingkungannya. Dalam teori behavioris, menurut Skinner mengatakan bahwa seluruh perilaku manusia dapat diamati sebagai respon yang terbentuk dari berbagai stimulus yang pernah di terima anak dari lingkungannya (Sujino, 2012). Keterlibatan anak dengan lingkungannya akan menunjukkan bagaimana bentuk dari perkembangan sosial anak, sehingga untuk menjadikan anak memiliki perilaku yang baik, maka lingkungan yang dimiliki anak juga harus mendukung pertumbuhan dan perkembangan anak (Izzaty, 2017; Vega et al., 2019).

Setiap orang tua menginginkan anaknya untuk menjadi anak yang memiliki pribadi yang baik dan dapat bersosialisasi dengan lingkungannya (Vega et al., 2019). Menurut Wiersond and Forehand, Orang tua merupakan contoh utama yang kuat bagi anak, yang dapat mengubah perilaku anak, karena anak lebih banyak berinteraksi dengan mereka (McIntyre \& Phaneuf, 2008; Scaramella \& Leve, 2004; Vega et al., 2019). Menurut Liliweri komunikasi antara orang tua dan anak sangat di perlukan dalam proses belajar anak karena anak belajar melalui teladan dari orang tua, dengan komunikasi orang tua dapat mengembangkan bahasa verbal anak serta kemampuan bersosialisasi anak dengan lingkungan belajar sekitar anak (Mariska, 2014).

Komunikasi adalah kemampuan beradaptasi saat keluarga merespon perubahan perkembangan dan kebutuhan situasional (Givertz \& Segrin, 2014). Ada beberapa tipe komunikasi orang tua (Ferlina \& Agustina, 2015), yang di antaranya komunikasi terbuka, komunikasi permukaan, komunikasi mengabaikan, komunikasi otoriter, komunikasi satu arah dan tanpa komunikasi. Orang tua perlu memiliki kontrol dalam menerapkan komunikasi pada anak, sehingga ada keseimbangan di dalam keluarga tersebut. Komunikasi yang baik yang dapat di terapkan di dalam keluarga adalah komunikasi positif. Komunikasi positif yang di maksud adalah empatik, mendengarkan dengan perhatian, berbicara untuk diri sendiri dan bukan untuk orang lain, dan tetap pada topik pembicaraan (Givertz \& Segrin, 2014).

Dalam hubungan timbal balik antara keluarga, ada dua jenis komunikasi yang terjadi yaitu komunikasi terbuka dan komunikasi tidak terbuka (Ponnet et al., 2013). Menurut Olson \& Goral (Givertz \& Segrin, 2014) jenis komunikasi orang tua yang baik adalah komunikasi terbuka, karena dengan menerapkan komunikasi terbuka, tingkat rasa bersalah anak dan kebencian anak akan rendah. Selain itu, menurut De Vito (Permatasari et al., 2020) ada empat tipe pola komunikasi yaitu; pola komunikasi persamaan (tiap individu memiliki kesempatan yang sama dalam berkomunikasi); pola komunikasi Seimbang terpisah (tiap orang memiliki daerah komunikasinya masing-masing); pola komunikasi tak seimbang terpisah (satu orang yang memegang kontrol karena memiliki kecerdasan yang lebih tinggi); dan pola komunikasi monopoli (satu orang dipandang sebagai pemegang kekuasaan dalam dalam menentukan keputusan). 
Orang tua menggunakan berbagai macam tipe komunikasi dengan alasan yang berbeda-beda. Ada orang tua memiliki kecemasan yang sangat tinggi, atau terlalu khawatir karena pernah mengalami kejadian negatif. Hal tersebut membuat komunikasi antara orang tua dan anak tidak terbuka, sehingga mereka menggunakan pola asuh yang bermasalah, tidak sabaran, menerapkan hukuman, serta pernyataan mereka yang tidak dapat dibantah (Bayer et al., 2006).

Meskipun peran komunikasi orang tua penting bagi perkembangan bahasa anak, masih banyak orang tua yang mengabaikan komunikasi seperti apa yang mereka terapkan terhadap anak. Bahkan, ketika anak-anak mereka mengucapkan kata kasar kepada mereka atau kepada teman sebayanya, orang tua hanya mengabaikan bahkan tertawa seakan-akan itu adalah hal yang lucu. Selain itu ada juga orang tua atau orang dewasa lainnya membiarkan anak-anak ketika mereka tiba-tiba memukul orang lain. Orang tua mengabaikannya karena beranggapan anak-anak masih belum mengerti apa-apa. Perilaku seperti itu disebut dengan perilaku agresif.

Ada banyak tipe dan jenis-jenis agresif, dan bagaimana anak mengekspresikan agresif mereka (Mouratidou et al., 2020). Perilaku agresif biasanya ditandai dengan anak yang suka mengganggu teman-temannya atau orang lain dengan cara mengucapkan kata kasar, membentak atau dengan fisik seperti memukul, menendang, mencubit, dan meludah (GilliesRezo \& Bosacki, 2003; Renouf et al., 2010; Sandstrom \& Jordan, 2008). Agresif adalah segala bentuk perilaku yang dimaksudkan untuk menyakiti atau melukai makhluk hidup (Antasari, 2006). Perilaku yang menyakiti dan melukai biasanya dianggap mengganggu oleh orang lain, selain mengganggu perilaku ini dianggap menghambat sosialisasi positif di lingkungan sekitar anak (Vazsonyi \& Keiley, 2007), sehingga anak-anak yang memiliki perilaku seperti ini biasanya tidak disukai oleh lingkungannya atau teman sebayanya karena dianggap tidak bersahabat (Findlay et al., 2006).

Sesuai hasil data dari KPAI tahun 2019 (Vega et al., 2019), kasus kekerasan di Indonesia sering terjadi di institusi pendidikan. Dari data yang sudah dibuktikan pada tahun 2011-2018 oleh Komisi Nasional Perlindungan Anak, terdapat 1664 kasus kekerasan yang terjadi disekolah.

Dari hasil observasi awal yang dilakukan di sekolah taman kanak-kanak yang terdapat di daerah Tapanuli Utara pada bulan Agustus 2019, anak yang memiliki tingkah agresif menjadi gangguan bagi lingkungan sekitar anak, seperti halnya di sekolah ketika anak belajar dan bermain dengan teman-temannya. Mereka sering mengganggu dengan cara mendorong, memukul bahkan membentak teman yang tidak menuruti keinginannya atau ketika perebutan mainan. Selain itu, mereka juga akan melempar mainan yang mereka pegang terhadap teman yang dianggap mengganggu mereka.

Penelitian yang dilakukan di taman kanak-kanak daerah Rawamangun pada tahun 2014, menemukan bahwa ada beberapa jenis perilaku agresif yang biasanya muncul pada anak usia dini. Perilaku agresif tersebut adalah agresif fisik, agresif meledak, agresif lisan dan agresif tidak langsung (Arriani, 2014). Agresif fisik yaitu jenis perilaku yang melukai orang lain dengan cara memukul atau menendang. Agresif yang meledak yaitu jenis perilaku yang marah-marah, mengancam atau membentak orang lain ketika merasa terganggu. Agresif lisan yaitu jenis perilaku agresif yang mengucapkan kata kasar. Agresif secara tidak langsung yaitu jenis perilaku yang menyalahkan orang lain atas kesalahan yang dibuatnya sendiri.

Perilaku agresif bisa muncul ketika anak merasa tertekan, ingin mencari perhatian orang lain, atau anak sering melihat orang di sekitarnya melakukan hal yang sama. Menurut Study Multivariat, ada beberapa faktor yang dapat menyebabkan perilaku agresif pada anak, seperti sosial ekonomi rendah, pola asuh orang tua, permusuhan dalam keluarga, perawatan anak, kejiwaan ibu, tidak konsistennya orang tua, dan juga pemaksaan yang dilakukan pada anak (Lyons-Ruth \& Melnick, 2004).

Anak akan meniru orang yang dikaguminya (Santrock, 2016). Anak-anak senang meniru segala sesuatu yang tidak pernah di lihatnya sebelumnya dan ingin mencoba hal baru 
tersebut (Rohayati, 2013). Perilaku agresif merupakan sesuatu yang di pelajari dan bukannya perilaku yang dibawa individu sejak lahir, perilaku agresif di pelajari dari lingkungan sosial seperti interaksi dengan keluarga, interaksi dengan rekan sebaya dan media massa dengan modelling (Gerde et al., 2013). Jika perilaku agresif tidak segera ditangani, perilaku ini akan berdampak hingga anak tumbuh remaja. Perilaku agresif yang dibiarkan begitu saja akan menjadi juvenile diliquence, perilaku ini merupakan jenis perilaku yang sering disebut sebagai kenakalan remaja (Izzaty, 2017; Schepers, 2017).

\section{METODOLOGI}

Penelitian ini menggunakan jenis penelitian deskriptif kuantitatif dengan metode komparatif. Peneliti memilih jenis penelitian ini untuk mengetahui ada atau tidaknya perbedaan antara dua atau lebih kelompok dalam aspek atau variabel yang diteliti, sehingga dapat menggambarkan pengaruh komunikasi orangtua terhadap perilaku agresif verbal anak. Penelitian ini dilakukan di PAUD Tunas Harapan yang terdapat di Kabupaten Tapanuli Utara pada bulan Januari 2020, dengan banyak populasi sebanyak 40 orang anak berusia 5-6 tahun. Pengambilan sampel dilakukan dengan cara sampling jenuh, yang artinya seluruh populasi dijadikan sebagai sampel. Hal ini dilakukan karena jumlah populasi yang dianggap relatif kecil.

Teknik pengumpulan data yang digunakan dalam penelitian ini adalah pertama dengan cara observasi terstruktur yang dilakukan oleh peneliti sendiri untuk melihat perilaku agresif verbal yang muncul pada anak. Observasi dilakukan kepada seluruh anak, yang artinya peneliti terlibat langsung dalam kegiatan sehari-hari yang dilakukan oleh anak, sehingga peneliti mendapatkan informasi yang sebenarnya tentang perilaku agresif verbal anak. Kedua data dikumpulkan menggunakan angket tertutup yang tersusun secara terstruktur untuk melihat jenis komunikasi orang tua. Angket akan dibagikan kepada setiap orang tua anak melalui guru kelas.

Analisis data dilakukan dengan cara, pertama mengumpulkan informasi tentang agresif verbal menggunakan observasi, yang kemudian dianalisis untuk menentukan tingkat interpretasi agresif verbal anak. Lembar observasi yang digunakan dalam bentuk checklist dengan skala pengukuran tipe Guttman, dengan pemberian bobot skor penilaian untuk jawaban "ya" diberi skor 1 dan jawaban "tidak" diberi skor 0. Kedua, mengumpulkan informasi tentang komunikasi orang tua dengan cara menganalisis hasil angket yang sudah diisi oleh orang tua. Lembar angket yang digunakan juga dalam bentuk checklist dengan bobot skor yang sama dengan lembar observasi. Setelah itu, menentukan perbedaan komunikasi orang tua terhadap perilaku agresif verbal anak, kemudian data akan diuji untuk melihat seberapa besar pengaruh komunikasi orang tua terhadap perilaku agresif verbal anak, dan yang terakhir adalah menarik kesimpulan. Secara lebih rinci paparan desain penelitian dapat dilihat pada gambar 1.
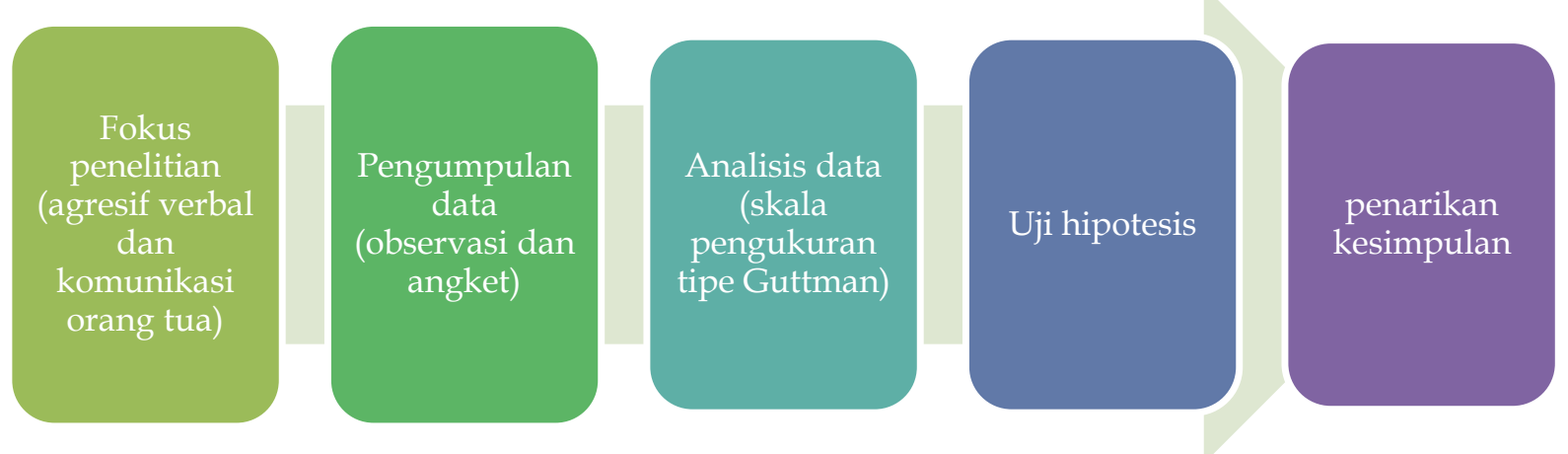

Gambar 1. Desain Penelitian 


\section{HASIL DAN PEMBAHASAN}

\section{Bentuk Perilaku Agresif Verbal Anak Usia 5-6 tahun}

Dari penelitian yang dilakukan, temuan pertama kata-kata kasar yang muncul atau kata-kata kasar yang sering diucapkan saat anak merasa marah atau merasa kesal dalam lingkungan sekolah yaitu pertama "oto"(bahasa daerah batak toba) yang jika diartikan dalam bahasa Indonesia memiliki arti "bodoh". Biasanya, anak mengucapkan kata ini saat anak merasa terganggu dengan temannya yang lain dan ketika anak mengejek hasil karya temannya di dalam proses pembelajaran berlangsung dan saat anak sedang dalam proses melakukan permainan.

Kedua, yang sering muncul adalah kata "hupamate maho"(bahasa daerah batak toba). Kata ini merupakan salah satu jenis dari ancaman, yang jika diartikan dalam bahasa Indonesia, artinya adalah "kubunuhlah kau?". Biasanya, anak mengucapkan kata ini saat anak merasa terganggu atau kesal terhadap temannya ketika anak sedang bermain.

Ketiga, kata kasar yang sering muncul adalah kata "pepet" (bahasa daerah batak toba). Kata ini merupakan nama alat kelamin untuk seorang wanita. Biasanya, anak mengucapkan kata ini ketika anak merasa terganggu saat anak sedang bermain.

Keempat, kata kasar yang sering muncul adalah kata "tai" . Kata ini akan diucapkan anak kepada teman sebayanya saat anak merasa terganggu ketika sedang bermain atau saat sedang melakukan proses pembelajaran. Dalam proses pembelajaran, anak dengan sengaja mengucapkan kata ini kepada temannya ketika temannya mengambil alat tulisnya tanpa seizin darinya.

Kelima, anak juga pernah menyebut temannya dengan sebutan hewan, contohnya menyebutkan temannya dengan sebutan "babi!", namun kata ini tidak terlalu sering muncul dalam proses pembelajaran di kelas, kata ini hanya pernah sekali terdengar oleh peneliti ketika anak bertengkar saat anak pulang dari sekolah.

Keenam, perilaku yang muncul ketika anak sedang kesal adalah anak berlagak kepada anak lainnya, dengan cara memberitahukan teman sebayanya pekerjaan orang tuanya dan memberitahu temannya bahwa orang tuanya bekerja di dekat sekolah, namun hal ini terlihat ketika anak pulang dari sekolah.

Ketujuh, anak juga mau membentak temannya. Salah satu contohnya, anak membentak teman untuk tidak mengambil alat tulisnya, contoh selanjutnya, anak akan membentak temannya untuk tidak mengganggunya saat mengerjakan sesuatu, atau ketika anak sedang bermain seluncuran. Anak akan membentak temannya ketika dia didahului saat menaiki tangga seluncurannya, dan membentak anak yang tidak disukainya juga menaiki permainan yang sama dengannya.

Selanjutnya, perilaku kasar yang muncul pada anak ketika anak sangat marah adalah, anak menyebut salah satu nama orangtua teman yang membuatnya marah, ketika mereka berdebat tentang sesuatu hal, atau keduanya tidak sependapat dengan suatu hal. Anak akan merasa kesal dan saling menyebutkan nama orangtua dari lawan debatnya. Namun, hal ini tidak terlalu sering terjadi dibandingkan kata-kata kasar yang sudah dipaparkan diatas. Untuk lebih jelasnya, dibawah ini akan disebutkan kata-kata yang muncul ketika anak merasa kesal, terganggu atau marah.

Tabel 1 menunjukkan bahwa ada berbagai macam jenis agresif verbal yang muncul pada anak usia 5-6 tahun ketika mereka merasa marah dan kesal. Hal ini ditemukan saat anak bermain atau sedang melakukan aktivitas belajar di dalam kelas. Agresif verbal yang muncul adalah mengejek, berlagak, bicara kotor dan kasar, menyebut temannya dengan nama hewan, menyebut temannya dengan nama orang tuanya, mengancam, dan membentak.

Berdasarkan data yang diperoleh dari distribusi frekuensi data hasil observasi agresif verbal anak, diketahui skor tertinggi $=15$, skor terendah $=1$, mean $=9,8(65,3 \%), \mathrm{Sd}=4,01$ sehingga nilai rata-rata berada pada kelas interval 7,9 - 10,1 dengan frekuensi 7 orang anak berada pada skor rata-rata, 8 orang anak berada dibawah rata-rata dan 25 orang anak berada diatas rata-rata. 
Tabel 1. Kata kasar yang sering diucapkan anak

\begin{tabular}{lllll} 
No $\quad \begin{array}{c}\text { Contoh Perilaku } \\
\text { Agresif Verbal }\end{array}$ & Kata Yang Sering Muncul \\
\hline$\quad$ Mengejek &
\end{tabular}

"jelek"

Kata ini sering muncul saat anak mengerjakan tugas dari guru.

2 Berlagak

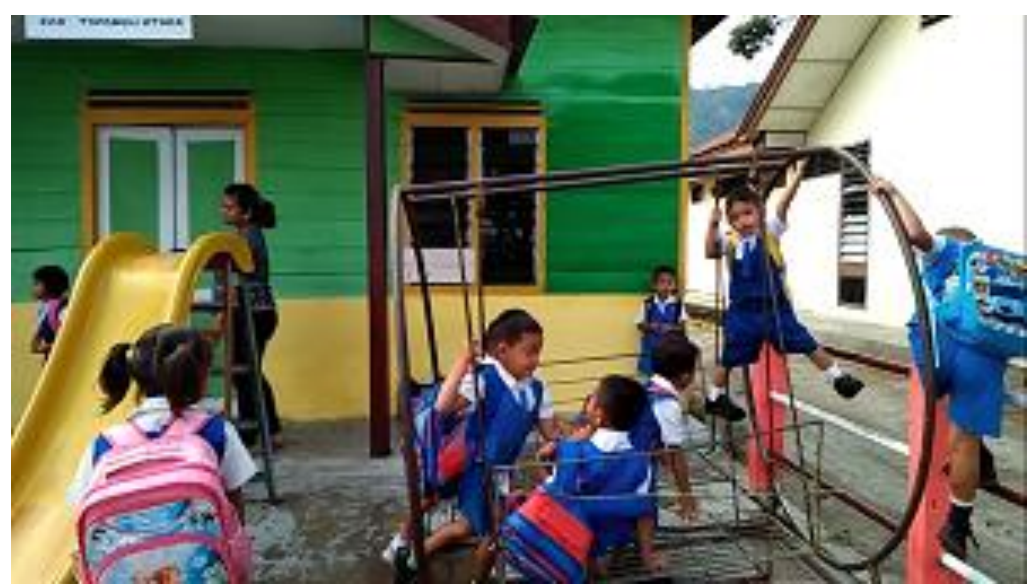

“apa kau! Bapak aku polisi. Nanti aku kasih tau sama bapakku” Hal ini terjadi ketika anak sedang bermain dan saling berlagak tentang pekerjaan orang tuanya.

3 Bicara kotor dan kasar

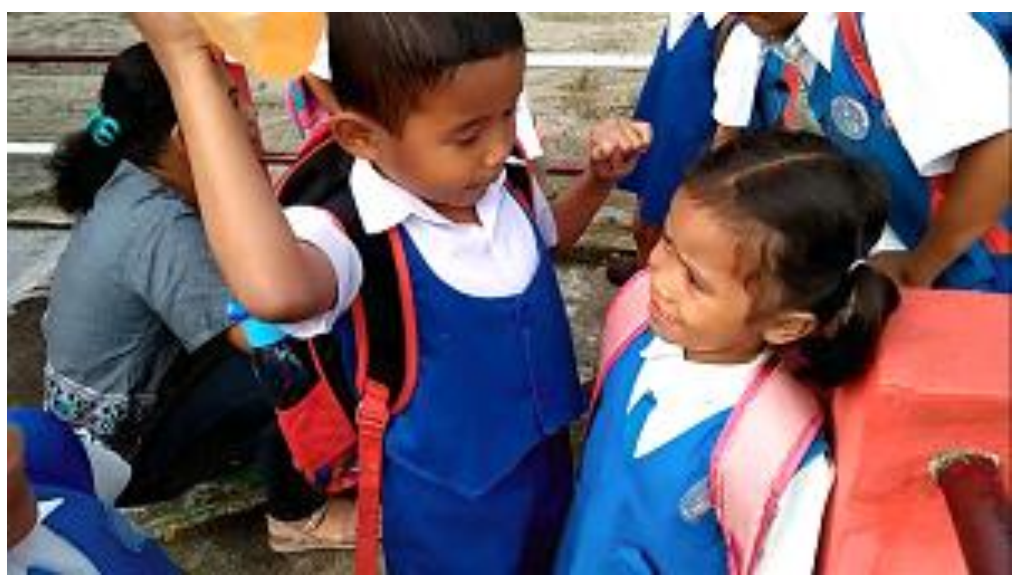

"Oto" (bodoh), "pepet" (alat kelamin perempuan), "tai"

Kata ini muncul ketika anak sedang bermain dan seseorang mengganggunya. 


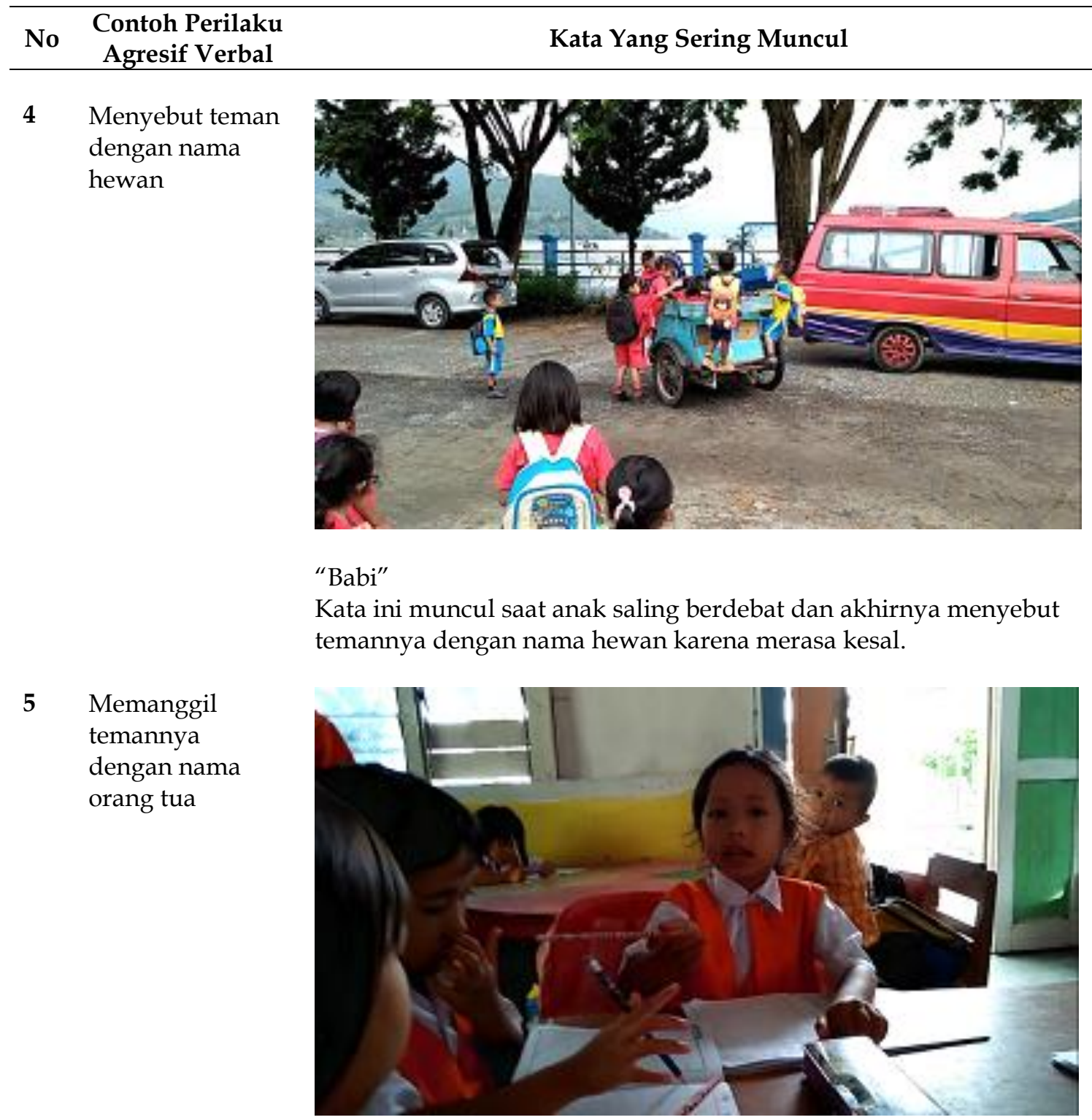

Anak menyebut nama orangtua dari temannya ketika anak merasa terganggu.

6 Mengancam

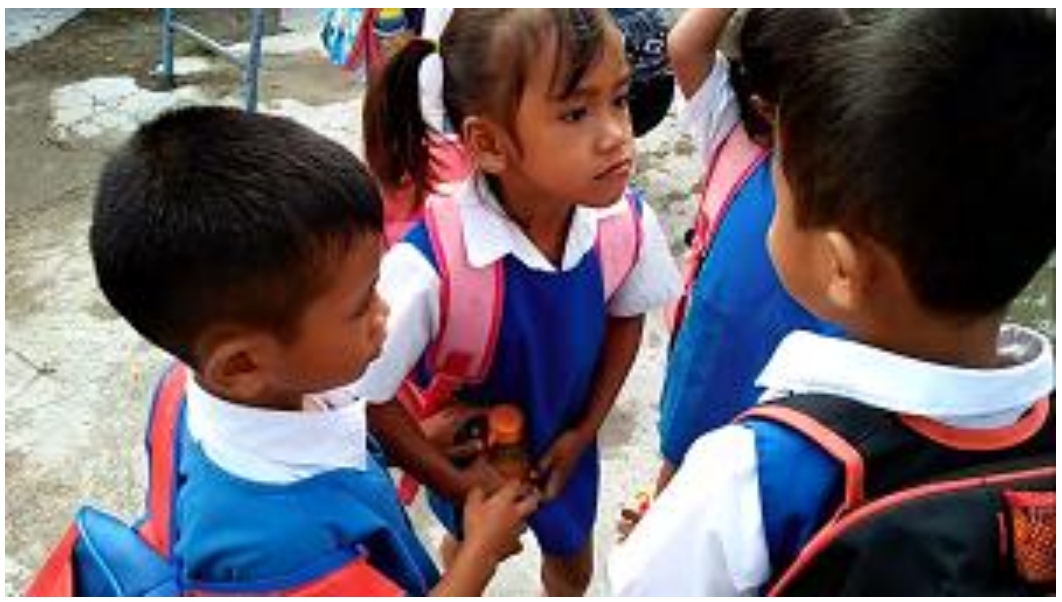

“hupamate maho!" (kubunuhlah kau)

Kata ini muncul saat anak merasa kesal dengan temannya karena telah mengganggunya. 


\begin{tabular}{cc} 
No $\begin{array}{c}\text { Contoh Perilaku } \\
\text { Agresif Verbal }\end{array}$ & Kata Yang Sering Muncul \\
\hline Membentak & \\
& "Awas ho!" (awas kamu!) \\
Anak membentak teman yang tidak disukainya memainkan \\
permainan yang sama dengannya.
\end{tabular}

Untuk lebih jelasnya mengenai data hasil observasi tentang perilaku agresif verbal pada anak usia 5-6 tahun, dapat ditunjukkan melalui tabel 2.

Tabel 2 .Interpretasi Skor Agresif verbal Anak Usia 5-6 Tahun

\begin{tabular}{ccccc}
\hline No & Besar Skor (\%) & Frekuensi & Persentase Nilai & Interpretasi \\
\hline 1 & $68 \%-100 \%$ & 25 & $62,5 \%$ & Tinggi \\
2 & $34 \%-67 \%$ & 9 & $22,5 \%$ & Sedang \\
3 & $0 \%-33 \%$ & 6 & $15 \%$ & Rendah \\
& Jumlah & 40 & $100 \%$ & \\
\hline
\end{tabular}

Hasil observasi agresif verbal anak usia 5-6 tahun, dilakukan dengan pemberian bobot skor untuk jawaban "ya" diberi skor 1 dan jawaban "tidak" diberi skor 0. Pemberian bobot skor ini dilakukan dengan skala pengukuran tipe Guttman, sehingga didapat interpretasi skor sebagai berikut; $68 \%-100 \%=$ Tinggi; $34 \%-67 \%=$ Sedang; $0 \%-33 \%=$ Rendah.

Untuk lebih jelasnya hasil observasi perilaku agresif verbal dapat ditunjukkan dengan gambar 2 dibawah ini.

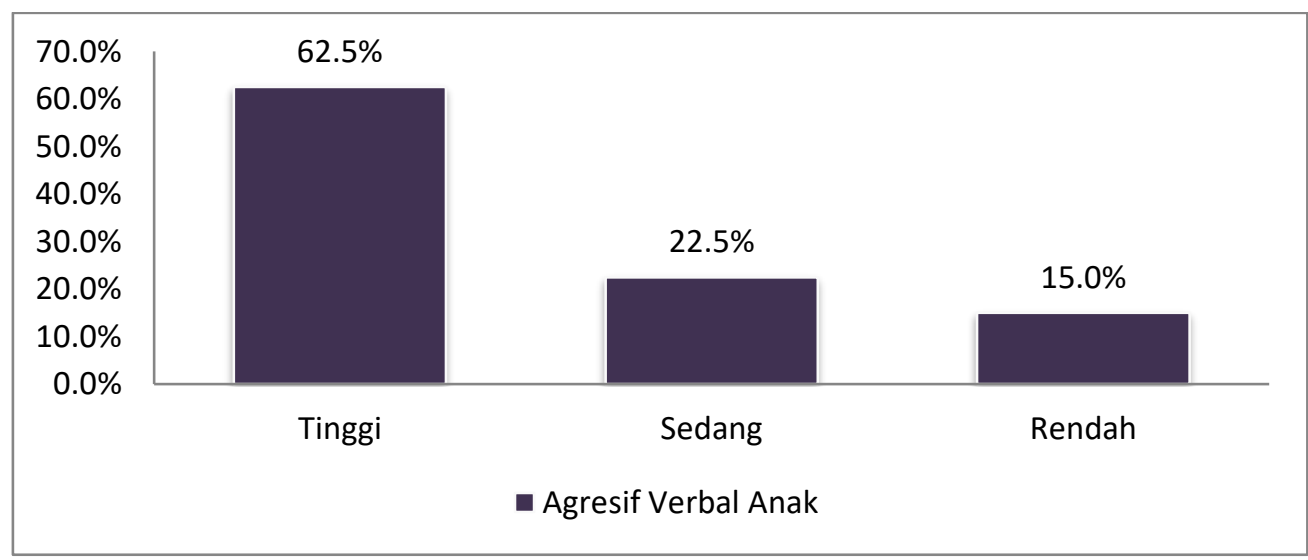

Gambar 2. Diagram Histogram Perilaku Agresif verbal Anak Usia 5-6 Tahun 
Berdasarkan dari gambar diagram di atas dapat diketahui hasil observasi perilaku agresif verbal anak diperoleh sebanyak 25 orang anak dengan tingkat persentase nilai antara $68 \%-100 \%$ dapat dikategorikan memiliki perilaku agresif verbal yang tinggi. Sebanyak 9 orang anak dengan tingkat persentase nilai antara 34\% - 67\% dapat dikategorikan memiliki perilaku agresif verbal yang sedang. Sebanyak 6 orang anak dengan tingkat persentase nilai antara $0 \%-33 \%$ dapat dikategorikan memiliki perilaku agresif verbal yang rendah. Dengan demikian, berdasarkan perhitungan hasil rata-rata, diperoleh bahwa agresif verbal anak usia 5-6 tahun berada pada kategori sedang.

\section{Bentuk Komunikasi Orang Tua}

Bentuk komunikasi orang tua dapat dilihat ketika orang tua menjemput anak dari sekolah. Dari hasil pengamatan yang dilakukan terhadap orang tua terlihat beberapa jenis komunikasi yang terjadi antara anak dan orangtua. Pertama, ketika orang tua menunggu anaknya di depan kelas dan anak berlari menjumpai orang tuanya, dengan cepat anak menceritakan apa yang dilakukan oleh anak di dalam kelas kepada orang tuanya. Pada saat yang sama, orang tua mendengarkan cerita anaknya, kemudian setelah anak selesai berbicara orang tua memberi tanggapan terhadap cerita anak. dalam hal ini, terjadi komunikasi terbuka antara anak dan orang tua.

Kedua, orang tua tidak menanyakan apa yang dilakukan oleh anaknya di sekolah dan dengan sikap yang terburu-buru, orang tua langsung menarik tangan anak agar anak cepat berjalan dan mengikutinya untuk segera pulang. Hal ini menandakan bahwa orangtua melakukan jenis komunikasi mengabaikan.

Ketiga, ketika anak dijemput oleh salah satu orang tuanya dan anak bertanya apa isi plastik yang sedang dipegang oleh orang tuanya, orang tua langsung menjawab anaknya dengan kata "bukan apa-apa, ,,,!!!". Hal ini menandakan bahwa orang tua melakukan jenis komunikasi permukaan / tidak terbuka.

Keempat, ada saat ketika orang tua menjemput anaknya, dan menemukan anaknya bermain tanah dengan anak yang lain, orang tuanya marah-marah sehingga membuat anak menangis. Pada saat itu, orang tua hanya memberi kata-kata dengan nada marah kepada anak. Dalam hal ini orang tua menunjukkan jenis komunikasi otoriter kepada anak.

Kelima, ada orang tua yang tidak membiarkan anaknya berbicara. Hal ini terjadi ketika anak berusaha memberikan alasan mengapa anak bermain dengan temannya yang lain di dekat kapal. Pada saat itu, orang tuanya lama menjemput anaknya dari sekolah. Berhubung sekolahnya dekat dengan daerah pelabuhan, anak tersebut mengikuti teman-temannya yang lain berjalan di sekitar kapal. Namun, ketika orang tuanya datang untuk menjemput, orang tua langsung memarahi si anak dan tidak membiarkannya untuk memberikan alasan mengapa anak bermain dengan temannya ditempat tersebut. Ada kejadian ini, orang tua menunjukkan jenis komunikasi satu arah kepada anak.

Yang terakhir, ada orang tua yang jarang menanyai atau berkomunikasi dengan anak, hal ini merupakan pendapat dari salah seorang guru yang mengajar ditempat penelitian. Kejadian ini terjadi karena orang tua bekerja sebagai seorang petani. Saat subuh, orang tua sudah pergi ke sawah sebelum anak berangkat ke sekolah, dan pulang pada saat menjelang malam, dan setelahnya orang tua pergi ke kedai tanpa banyak berbicara kepada anaknya, kejadian ini biasanya terjadi pada ayah sehingga jarang terjadi komunikasi dengan anak. Kejadian ini biasanya terjadi pada orang tua laki-laki atau ayah dari anak yang sangat sibuk dengan pekerjaannya. Hal ini juga sesuai dengan pendapat Indira (Khasanah \& Fauziah, 2020) yang mengatakan bahwa ada banyak faktor yang mempengaruhi pola asuh ayah, yang diantaranya situasi sosial-ekonomi orangtua, situasi tempat tinggal, dan waktu keluarga. Untuk lebih jelasnya perbedaan komunikasi orang tua dipaparkan pada tabel 3 dan diagram histogram komunikasi orang tua dapat dilihat melalui gambar 3. 
Tabel 3. Data komunikasi orangtua

\begin{tabular}{clcc}
\hline No & Jenis Komunikasi & Jumlah & Persentasi Nilai \\
\hline 1 & Terbuka & 6 & $15 \%$ \\
2 & Permukaan & 6 & $15 \%$ \\
3 & Mengabaikan & 8 & $20 \%$ \\
4 & Otoriter & 7 & $17,5 \%$ \\
5 & Satu Arah & 10 & $25 \%$ \\
6 & Tanpa Ada Komunikasi & 3 & $7,5 \%$ \\
& Jumlah & $\mathbf{4 0}$ & $\mathbf{1 0 0} \%$ \\
\hline
\end{tabular}

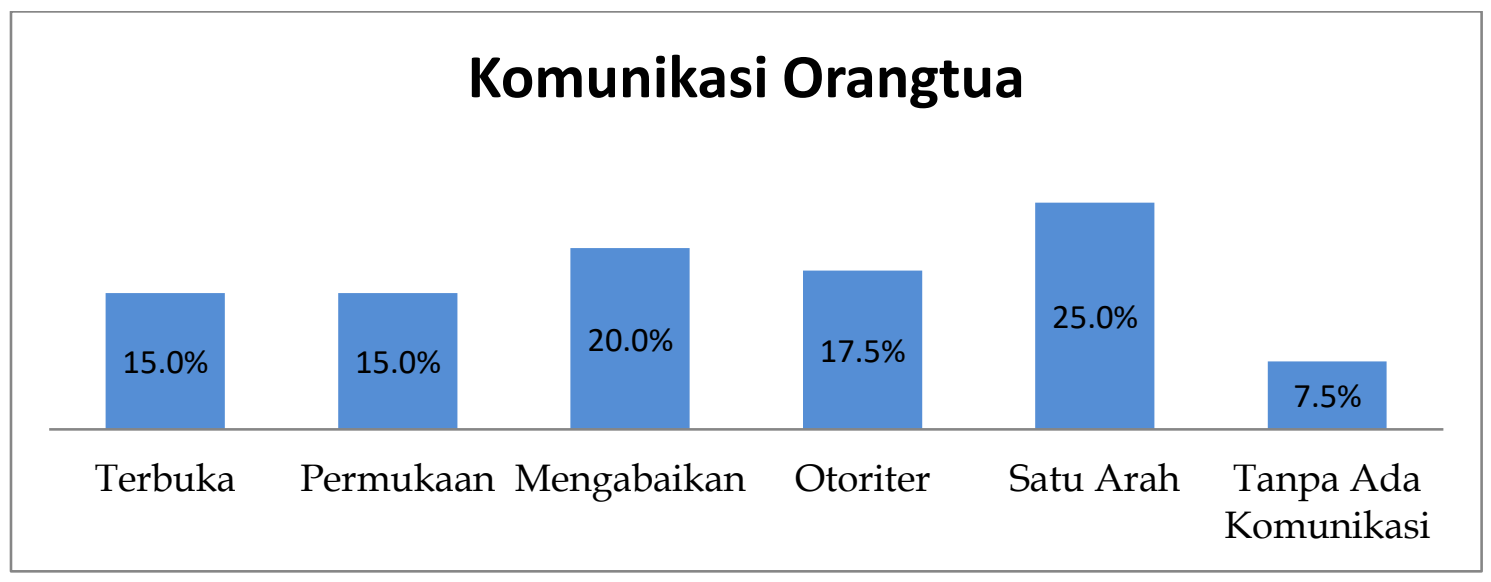

Gambar 3. Diagram Histogram Komunikasi Orang tua

Berdasarkan gambar 3, dapat dilihat bahwa terdapat 6 orang tua yang menerapkan jenis komunikasi terbuka dengan tingkat persentase sebesar 15\%, yang mana dalam komunikasi ini orang tua menanggapi dan menghargai pendapat anak. 6 orang tua menerapkan jenis komunikasi permukaan dengan tingkat persentase sebesar 15\%, yang mana dalam komunikasi ini orang tua tidak terbuka terhadap anak baik tentang perasaan orang tua atau permasalahan orang tua. 8 orangtua menerapkan jenis komunikasi mengabaikan, dengan tingkat persentase sebesar $20 \%$, yang mana dalam komunikasi ini masing-masing keluarga saling menghindar satu sama lain. 7 orang tua menerapkan jenis komunikasi otoriter dengan tingkat persentase sebesar 17,5\%, yang mana dalam komunikasi ini orang tua langsung memberi kesan marah kepada setiap pendapat anak. 10 orang tua menerapkan jenis komunikasi satu arah dengan tingkat persentase sebesar $25 \%$, yang mana dalam komunikasi ini hanya orang tua yang bisa berbicara atau memberi pendapat. 3 orang tua menerapkan jenis komunikasi tanpa ada komunikasi dengan tingkat persentase sebesar 7,5\%, yang mana dalam komunikasi ini tidak terjadi proses komunikasi antara orang tua dan anak, hal ini dapat disebabkan karena orang tua sibuk bekerja.

\section{Perbedaan Komunikasi Orang Tua terhadap Perilaku Agresif Verbal Anak}

Pengaruh komunikasi terhadap perilaku agresif verbal anak diuji menggunakan pearson chi square. Perbedaan komunikasi orangtua terhadap perilaku agresif verbal anak dapat dilihat pada tabel 3. Berdasarkan tabel 3, dari hasil angket komunikasi orang tua diketahui; dari 6 orang tua yang menerapkan komunikasi terbuka, terdapat 1 anak yang berperilaku agresif verbal tinggi, 4 anak agresif verbal sedang dan 1 anak agresif verbal rendah; dari 6 orang tua yang menerapkan komunikasi permukaan, terdapat 4 anak agresif verbal tinggi, 1 anak agresif verbal sedang dan 1 anak agresif verbal rendah; dari 8 orang tua yang menerapkan komunikasi mengabaikan, terdapat 6 anak agresif verbal tinggi, 1 anak agresif sedang, dan 1 anak agresif verbal rendah; dari 7 orang tua yang menerapkan komunikasi otoriter, terdapat 5 anak agresif verbal tinggi, 1 anak agresif verbal sedang dan 1 
anak agresif verbal rendah; dari 10 orang tua yang menerapkan komunikasi satu arah, terdapat 8 anak agresif verbal tinggi, 1 anak agresif verbal sedang dam 1 anak agresif verbal rendah; dari 3 orang tua yang menerapkan tanpa ada komunikasi, terdapat 1 anak agresif verbal tinggi, 1 anak agresif verbal sedang dan 1 anak agresif verbal rendah.

Tabel 3. Perbedaan Komunikasi Orangtua terhadap Perilaku Agresif Verbal

\begin{tabular}{|c|c|c|c|c|}
\hline \multirow{2}{*}{ Jenis komunikasi } & \multicolumn{3}{|c|}{ Perilaku agresif verbal } & \multirow[t]{2}{*}{ Jumlah } \\
\hline & 1 & 2 & 3 & \\
\hline A & 1 & 4 & 1 & 6 \\
\hline B & 4 & 1 & 1 & 6 \\
\hline C & 6 & 1 & 1 & 8 \\
\hline D & 5 & 1 & 1 & 7 \\
\hline $\mathrm{E}$ & 8 & 1 & 1 & 10 \\
\hline F & 1 & 1 & 1 & 3 \\
\hline Total & 25 & 9 & 6 & 40 \\
\hline
\end{tabular}

\section{Keterangan :}

Agresif verbal 1 = agresif verbal tinggi, agresif verbal $2=$ agresif verbal sedang, agresif verbal,dan $3=$ agresif verbal rendah. Jenis komunikasi $\mathrm{A}=$ komunikasi terbuka, jenis komunikasi $\mathrm{B}=$ komunikasi permukaan, jenis komunikasi $\mathrm{C}=$ Komunikasi mengabaikan, jenis komunikasi $\mathrm{D}=$ Komunikasi otoriter, jenis komunikasi $\mathrm{E}=$ Komunikasi satu arah, dan jenis komuniakasi $\mathrm{F}=$ tanpa ada komunikasi.

Taraf signifikan yang digunakan dalam penelitian ini adalah a $5 \%=(0,05)$ dengan $d k$ $=(6-1)(3-1)=10$, dan berdasarkan tabel nilai-nilai Chi Kuadrat diperoleh $X^{2}{ }_{t}=18,31$ dan dari hasil penghitungan diperoleh nilai dari $X^{2}{ }_{h}$ adalah 22,1023. Sehingga dapat disimpulkan perbedaan komunikasi orangtua memiliki pengaruh yang signifikan terhadap perilaku agresif verbal anak usia 5-6 tahun. Selain itu, komunikasi yang dilakukan oleh tiap orangtua berbeda satu sama lainnya. Dari hasil penelitian yang sudah dilakukan diperoleh bahwa komunikasi satu arah memiliki tingkat agresif verbal anak yang lebih tinggi dari pada jenis komunikasi lainnya.

\section{Pembahasan}

Berdasarkan hasil pengujian dan analisis data yang telah dilakukan sebelumnya, didapatkan bentuk perilaku agresif verbal anak usia 5-6 tahun adalah kata-kata kasar yang sering diucapkan oleh anak terhadap teman sebaya ketika anak merasa terganggu atau merasa kesal ketika mereka sedang melakukan permainan atau dalam proses pembelajaran. Biasanya, saat anak merasa terganggu anak sering mengucapkan kata-kata seperti; "oto" (bodoh), "huamate maho!" (kubunuhlah kau!), "pepet" (alat kelamin perempuan), "jelek", dan "Tai" (kotoran), bahkan anak sesekali akan mengucapkan nama hewan kepada temannya, memanggil nama orang tua temannya atau berlagak karena orang tuanya bekerja di dekat sekolahnya. Hal tersebut muncul ketika anak sudah merasa sangat marah dan kesal kepada temannya, sehingga anak mengucapkan kata kasar untuk melepas rasa marah yang ada dalam dirinya. Hal ini sesuai dengan penelitian Ariani (2014) yang mengatakan agresif yang muncul pada anak ada yang berupa lisan seperti kata kasar untuk mengintimidasi orang lain. Tindakan tersebut merupakan tindakan yang biasa dilakukan oleh anak sebagai hasil dari kemarahan atau frustasi.

Salah satu faktor yang mendukung terjadinya agresif verbal pada anak adalah komunikasi orang tua. Hal ini juga dikatakan oleh Albaiz \& Ernest (2020) dalam penelitiannya, bahwa keluarga yang paling dekatlah yang membentuk anak hingga ke masa depan, terasuk komunikasi yang mereka gunakan. Komunikasi orang tua yang dimaksud di sini adalah interaksi bahasa verbal yang digunakan dalam penyampaian informasi, pikiran, gagasan, dan emosi melalui kata-kata orang tua kepada anaknya. 
Bentuk komunikasi orang tua yang sering dilakukan pada anak oleh orang tua salah satunya dapat dilihat ketika orang tua menjemput anak dari sekolah. Salah satu contohnya ketika orang tua menjemput anaknya dari sekolah, dan anak berlari menemui orang tuanya, anak menceritakan kegiatan yang dilakukan anak selama disekolah kepada orang tua, orang tua menanggapi cerita anak dengan baik dan memberikan respon positif, contoh ;"mama, tadi kami bermain lego dan membuat kereta api yang sangat panjang.." "benarkah? Bagaimana kamu melakukannya? ....". Dalam percakapan itu, orang tua dan anak melakukan komunikasi terbuka karena orang tua membiarkan anaknya bercerita dan orang tua memberikan respon yang positif kepada anak.

Selain itu ada juga orang tua yang ketika anak bertanya kepada orang tuanya, mereka tidak menghiraukan perkataan anaknya, contoh; "ma, adik gk ikut?" "cepatlah naik! Kamu lama kali!..." hal tersebut merupakan komunikasi mengabaikan, karena orang tua tidak merespon pertanyaan anak dan segera menyuruh anak untuk segera naik keatas kendaraan.

Selanjutnya, ada orang tua yang tidak terbuka pada anak, contoh; "ma, apa yang ada dalam pastik itu?" "ah! Sudedo sukkkunonmu! (ah, semua kamu tanyai)..." hal ini merupakan contoh komunikasi permukaan. Dilain sisi, ada orangtua yang langsung marah-marah kepada anaknya ketika anaknya sedang bermain dengan teman-temannya dan tidak segera pulang kerumah, "contohnya; "... ai marhuai doho disi? Hatop mulak!" (kamu napain disana? Cepat pulang!). Dalam hal tersebut orangtua menerapkan komunikasi otoriter, karena orang tua langsung marah-marah kepada anak.

Selanjutnya, ada orang tua yang tidak memperbolehkan anaknya memberikan alasan, ketika anak memberikan alasan kenapa anak bermain, orang tua langsung menyela pembicaraan anak, contoh "ma..." "diam kau! Cepat pulang!". Dalam situasi tersebut, orang tua menggunakan komunikasi satu arah karena anak tidak boleh berbicara dan anak hanya menuruti apa yang dikatakan orang tua.

Selanjutnya ada orang tua yang menerapkan komunikasi tanpa ada komunikasi, hal ini terjadi ketika orang tua sibuk bekerja ke sawah. Orang tua memiliki waktu yang sangat minim dengan anak dikarenakan pada pagi hari sebelum anak berangkat sekolah, orang tua sudah pergi ke sawah, dan setelah pulang dari sawah pada sore hari, orang tua sudah pergi ke kedai tanpa banyak menanyakan apa saja yang dilakukan anaknya selama satu hari ketika orang tua bekerja. Kesibukan yang dimiliki orang tua dapat mengakibatkan waktu bersama anak-anak memiliki keterbatasan. Hal ini dipengaruhi oleh banyak hal, seperti situasi sosialekonomi orang tua, dan situasi tempat tinggal orang tua (Khasanah \& Fauziah, 2020), namun meskipun demikian ada baiknya orang tua menyempatkan waktu untuk berkomunikasi dengan anak. Seperti halnya yang dikatakan oleh Harmaini (Kurniati et al., 2020) bahwa kebersamaan orang tua sangat diperlukan karena mereka yang memahami tingkatan perkembangan anak, serta hal yang dibutuhkan oleh anak.

Ada beberapa bentuk-bentuk komunikasi yang diterapkan orang tua dilingkungan anak (Ferlina \& Agustina, 2015) yaitu, 1) komunikasi terbuka yaitu anak dan orangtua saling terbuka. 2) komunikasi permukaan (tidak terbuka) yaitu komunikasi yang tidak terwujud karena tidak ada keterbukaan. 3) komunikasi mengabaikan yaitu komunikasi yang tidak ada kepedulian. 4) komunikasi otoriter yaitu komunikasi yang cenderung menuntut. 5) komunikasi satu arah yaitu komunikasi yang hanya ada satu figure dominan. 6) tanpa ada komunikasi, yaitu antara sesama keluarga jarang ada komunikasi atau pembicaraan. Sementara menurut Olson \& Goral (Givertz \& Segrin, 2014) komunikasi orang tua yang baik adalah komunikasi terbuka. Menurut mereka, komunikasi terbuka akan membuat tingkat rasa bersalah anak dan kebencian anak akan rendah. komunikasi terbuka dapat menciptakan keseimbangan dalam keluarga (Givertz \& Segrin, 2014), dan komunikasi tidak terbuka dapat menyebabkan perilaku anak yang menyimpang (Ponnet et al., 2013)

Berdasarkan hasil pengujian data dan analisis yang telah dilakukan, didapatkan bahwa komunikasi orang tua berbeda satu sama lainnya, dimana komunikasi satu arah memiliki tingkat agresif verbal anak yang lebih tinggi dari pada jenis komunikasi lainnya. Hal 
tersebut dilihat dari 6 orang tua yang menerapkan komunikasi terbuka, terdapat 1 anak yang berperilaku agresif verbal tinggi, 4 anak agresif verbal sedang dan 1 anak agresif verbal rendah. Dari 6 orangtua yang menerapkan komunikasi permukaan, terdapat 4 anak agresif verbal tinggi, 1 anak agresif verbal sedang dan 1 anak agresif verbal rendah. Dari 8 orang tua yang menerapkan komunikasi mengabaikan, terdapat 6 anak agresif verbal tinggi, 1 anak agresif sedang, dan 1 anak agresif verbal rendah. Dari 8 orang tua yang menerapkan komunikasi mengabaikan, terdapat 6 anak agresif verbal tinggi, 1 anak agresif sedang, dan 1 anak agresif verbal rendah. Dari 7 orang tua yang menerapkan komunikasi otoriter, terdapat 5 anak agresif verbal tinggi, 1 anak agresif verbal sedang dan 1 anak agresif verbal rendah.

Dari 10 orang tua yang menerapkan komunikasi satu arah, terdapat 8 anak agresif verbal tinggi, 1 anak agresif verbal sedang dam 1 anak agresif verbal rendah. Serta dari 3 orang tua yang menerapkan komunikasi tanpa ada komunikasi, terdapat 1 anak agresif verbal tinggi, 1 anak agresif verbal sedang dan 1 anak agresif verbal rendah. Selanjutnya, dari hasil pengujian data tersebut didapat ada pengaruh yang signifikan komunikasi orang tua terhadap perilaku agresif verbal anak usia 5-6 tahun. Hal ini dapat ditinjau dari hasil penelitian yang menunjukkan perhitungan dari uji chi square diperoleh $\mathrm{X}^{2}{ }_{h}=22,1023$ dan $\mathrm{X}^{2}{ }_{\mathrm{t}}=18,31$ dengan taraf signifikansi 0,$05 ; d k=(b-1)(k-1)=10$, maka $X^{2}{ }_{h}>X^{2}{ }_{t}$ sehingga Ha diterima dan Ho ditolak, dengan demikian hipotesis yang menyatakan bahwa ada pengaruh yang signifikan dari perbedaan komunikasi orang tua terhadap perilaku agresif verbal anak usia 5-6 tahun. Hal ini sesuai dengan hasil penelitian yang dilakukan di TK Kenanga Kabupaten Bandung barat, bahwa keterlibatan orang tua akan sangat berpengaruh terhadap perilaku anak usia dini (Robbiyah et al., 2018). Selain itu, penelitian lain juga menemukan bahwa pola asuh yang diterapkan oleh orang tua termasuk komunikasi yang digunakan dapat memberikan dampak bagi perkembangan anak, seperti perkembangan sosial dan emosi anak (Kusumawardani \& Fauziah, 2020).

\section{SIMPULAN}

Komunikasi orang tua sangat penting dalam membentuk perilaku anak usia 5-6 tahun. Jenis komunikasi yang di terapkan oleh orang tua terhadap anak dapat menentukan bagaimana anak akan berkomunikasi di lingkungannya, sehingga anak dapat bersosialisasi dengan orang lain. Setiap orang tua memiliki cara tersendiri untuk berkomunikasi dengan anaknya. Buruknya komunikasi yang di terapkan oleh orang tua kepada anak dapat memunculkan perilaku agresif verbal pada anak. Bentuk komunikasi orang tua yang dapat memunculkan perilaku agresif verbal pada anak adalah saat komunikasi orang tua dan anak tidak terbuka, orang tua yang mengabaikan perkataan anak, komunikasi yang bersifat otoriter, dan komunikasi satu arah.

\section{UCAPAN TERIMA KASIH}

Terimakasih saya ucapkan kepada Tuhan Yang Maha Esa, orang tua, kepala sekolah, dan teman-teman guru yang banyak membantu, mendukung, dan memberi saya izin untuk melakukan penelitian ini. Penyelesaian tulisan ini juga tidak terlepas dari bantuan dari pihak lain. Teman-teman sekelas yang banyak memberi arahan. Orang tua yang selalu memberikan motivasi dan doa. Peneliti juga mengucapkan terimakasih kepada Dewan Redaksi Jurnal Obsesi yang memberi peneliti kesempatan untuk membagi ilmu.

\section{DAFTAR PUSTAKA}

Albaiz, N. E. A., \& Ernest, J. M. (2020). Exploring Saudi Kindergarten Teachers' Views and Uses of School, Family, and Community Partnerships Practices. Early Childhood Education Journal, Gent 2009. https://doi.org/10.1007/s10643-020-01091-z

Antasari. (2006). Perilaku agresif anak. Pustaka Belajar.

Arriani, F. (2014). Perilaku Agresif Anak Usia Dini. Jurnal Pendidikan Usia Dini, 8(2), 263-274. 
Bayer, J. K., Sanson, A. V., \& Hemphill, S. A. (2006). Parent influences on early childhood internalizing difficulties. Journal of Applied Developmental Psychology, 27(6), 542-559. https://doi.org/10.1016/j.appdev.2006.08.002

Britto, P. R., Lye, S. J., Proulx, K., Yousafzai, A. K., Matthews, S. G., Vaivada, T., PerezEscamilla, R., Rao, N., Ip, P., Fernald, L. C. H., MacMillan, H., Hanson, M., Wachs, T. D., Yao, H., Yoshikawa, H., Cerezo, A., Leckman, J. F., \& Bhutta, Z. A. (2017). Nurturing care: promoting early childhood development. The Lancet, 389(10064), 91-102. https:/ / doi.org/10.1016/S0140-6736(16)31390-3

Ferlina, J. M., \& Agustina. (2015). Meningkatkan Kemampuan Berkomunikasi Aktif pada Anak Usia Dini. PT LUXIMA METRO MEDIA.

Findlay, L. C., Girardi, A., \& Coplan, R. J. (2006). Links between empathy, social behavior, and social understanding in early childhood. Early Childhood Research Quarterly, 21(3), 347359. https:// doi.org/10.1016/j.ecresq.2006.07.009

Gerde, H. K., Schachter, R. E., \& Wasik, B. A. (2013). Using the Scientific Method to Guide Learning: An Integrated Approach to Early Childhood Curriculum. Early Childhood Education Journal, 41(5), 315-323. https://doi.org/10.1007/s10643-013-0579-4

Gillies-Rezo, S., \& Bosacki, S. (2003). Invisible bruises: Kindergartners' perceptions of bullying. International Journal of Children's Spirituality, 8(2), 163-177. https://doi.org/10.1080/13644360304628

Givertz, M., \& Segrin, C. (2014). The Association Between Overinvolved Parenting and Young Adults' Self-Efficacy, Psychological Entitlement, and Family Communication. Communication Research, 41(8), 1111-1136. https://doi.org/10.1177/0093650212456392

Irma, C. N., Nisa, K., \& Sururiyah, S. K. (2019). Keterlibatan Orang Tua dalam Pendidikan Anak Usia Dini di TK Masyithoh 1 Purworejo. Jurnal Obsesi: Jurnal Pendidikan Anak Usia Dini, 3(1), 214. https://doi.org/10.31004/obsesi.v3i1.152

Izzaty, R. E. (2017). Perilaku Anak Prasekolah. 5.

Khasanah, B. L., \& Fauziah, P. (2020). Pola Asuh Ayah dalam Perilaku Prososial Anak Usia Dini. Jurnal Obsesi: Jurnal Pendidikan Anak Usia Dini, 5(1), 909-922. https://doi.org/10.31004/obsesi.v5i1.627

Kurniati, E., Nur Alfaeni, D. K., \& Andriani, F. (2020). Analisis Peran Orang Tua dalam Mendampingi Anak di Masa Pandemi Covid-19. Jurnal Obsesi : Jurnal Pendidikan Anak Usia Dini, 5(1), 241. https:// doi.org/10.31004/obsesi.v5i1.541

Kusumawardani, C. T., \& Fauziah, P. Y. (2020). Pola Asuh Orangtua Tentara Nasional Indonesia pada Anak Usia Dini. Jurnal Obsesi : Jurnal Pendidikan Anak Usia Dini, 5(2), 1024-1034. https:// doi.org/10.31004/obsesi.v5i2.620

Lyons-Ruth, K., \& Melnick, S. (2004). Dose-response effect of mother-infant clinical home visiting on aggressive behavior problems in kindergarten. Journal of the American Academy of Child and Adolescent Psychiatry, 43(6), 699-707. https:// doi.org/10.1097/01.chi.0000122730.72597.07

Mariska, G. (2014). Proses Komunikasi Orang Tua-Anak pada Keluarga dengan Ibu Bekerja dan Ayah sebagai Ayah Rumah Tangga. Jurnal E-Komunikasi, 2(1). https:// media.neliti.com/.../79443-ID-proses-komunikasi-orang-tua-anak-padake.pdf $\% 0 \mathrm{~A} \% 0 \mathrm{~A}$

McIntyre, L. L., \& Phaneuf, L. K. (2008). A Three-Tier Model of Parent Education in Early Childhood: Applying a Problem-Solving Model. Topics in Early Childhood Special Education, 27(4), 214-222. https://doi.org/10.1177/0271121407311239

Mouratidou, K., Karamavrou, S., Karatza, S., \& Schillinger, M. (2020). Aggressive and socially insecure behaviors in kindergarten and elementary school students: a comparative study concerning gender, age and geographical background of children in Northern Greece. Social Psychology of Education, 23(1), 259-277. https:// doi.org/10.1007/s11218019-09536-z

Permatasari, A. N., Inten, D. N., Wiliani, W., \& Widiyanto, K. N. (2020). Keintiman Komunikasi 
Keluarga saat Social Distancing Pandemi Covid-19. Jurnal Obsesi : Jurnal Pendidikan Anak Usia Dini, 5(1), 346. https:/ / doi.org/10.31004/obsesi.v5i1.577

Ponnet, K., Wouters, E., Mortelmans, D., Pasteels, I., De Backer, C., Van Leeuwen, K., \& Van Hiel, A. (2013). The influence of mothers' and fathers' parenting stress and depressive symptoms on own and partner's parent-child communication. Family Process, 52(2), 312-324. https://doi.org/10.1111/famp.12001

Renouf, A., Brendgen, M., Parent, S., Vitaro, F., David Zelazo, P., Boivin, M., Dionne, G., Tremblay, R. E., Pérusse, D., \& Séguin, J. R. (2010). Relations between theory of mind and indirect and physical aggression in kindergarten: evidence of the moderating role of prosocial behaviors. Social Development, 19(3), 535-555. https:// doi.org/10.1111/j.1467-9507.2009.00552.x

Robbiyah, R., Ekasari, D., Witarsa, R., \& Robbiyah, E. dan W. (2018). Pengaruh Pola Asuh Ibu terhadap Kecerdasan Sosial Anak Usia Dini di TK Kenanga Kabupaten Bandung Barat. Jurnal Obsesi, 2(1), 76-84. https:// doi.org/10.31004/obsesi.v2i1.10

Rohayati, T. (2013). Pengembangan perilaku sosial anak usia dini. Jurnal Cakrawala Dini, 4(2), 131-137. https://doi.org/10.17509/cd.v4i2.10392

Sandstrom, M. J., \& Jordan, R. (2008). Defensive self-esteem and aggression in childhood. Journal of Research in Personality, 42(2), 506-514. https:// doi.org/10.1016/j.jrp.2007.07.008

Santrock, J. W. (n.d.). LIFE-SPAN.

Scaramella, L. V., \& Leve, L. D. (2004). Clarifying parent-child reciprocities during early childhood: The early childhood coercion model. In Clinical Child and Family Psychology Review (Vol. 7, Issue 2, pp. 89-107). https:// doi.org/10.1023/B:CCFP.0000030287.13160.a3

Schepers, D. (2017). Causes of the causes of juvenile delinquency: Social disadvantages in the context of situational action theory. European Journal of Criminology, 14(2), 143-159. https:/ / doi.org/10.1177/1477370816649622

Sujino, Y. N. (2012). Konsep Dasar Pendidikan Anak Usia Dini. Indeks.

Trivette, C. M., Dunst, C. J., \& Hamby, D. W. (2010). Influences of Family-Systems Intervention Practices on Parent-Child Interactions and Child Development. Topics in Early Childhood Special Education, 30(1), 3-19. https://doi.org/10.1177/0271121410364250

Vazsonyi, A. T., \& Keiley, M. K. (2007). Normative developmental trajectories of aggressive behaviors in African American, American Indian, Asian American, Caucasian, and Hispanic children and early adolescents. Journal of Abnormal Child Psychology, 35(6), 1047-1062. https:/ / doi.org/10.1007/s10802-007-9154-z

Vega, A. De, Hapidin, H., \& Karnadi, K. (2019). Pengaruh Pola Asuh dan Kekerasan Verbal terhadap Kepercayaan Diri (Self-Confidence). Jurnal Obsesi : Jurnal Pendidikan Anak Usia Dini, 3(2), 433. https:// doi.org/10.31004/obsesi.v3i2.227 